\title{
COMPARATIVE STUDY OF CHEMICALLY AND MECHANICALLY SINGED KNIT FABRIC
}

\author{
M.A. Hannan', M. Zakaria ${ }^{2}$, A.H. Bhuiyan ${ }^{3}$, Shahjalal Khandaker ${ }^{4}$ \\ ${ }^{1}$ Asstt. Prof., Dept. of Textile Engg. Dhaka University of Engg and Tech, Gazipur, Bangladesh \\ ${ }^{2}$ Asstt. Prof., Dept. of Textile Engg. Dhaka University of Engg and Tech, Gazipur, Bangladesh \\ ${ }^{3}$ Lecturer, Dept. of Textile Engg Dhaka University of Engg and Tech, Gazipur, Bangladesh \\ ${ }^{4}$ Asstt. Prof., Dept. of Textile Engg. Dhaka University of Engg and Tech, Gazipur, Bangladesh
}

\begin{abstract}
Single jersey cotton knit fabric of 162 GSM was singed both chemically (enzyme treatment) and mechanically. Mechanically singed fabric exhibited more brightness and whiteness than chemically singed fabric and in the same manner chemically singed fabric resulted more yellowness than mechanically singed fabric. The color fastness to washing of the treated fabric experienced almost same results in both of the cases. On the other hand chemically singed fabric focused on prevailing more strength than mechanically singed one which was evaluated by bursting strength test. Eventually the CMC value of the chemically and mechanically singed, and then dyed, fabric remained within acceptable range. Microscopic view of the treated samples was also taken to capture the surface hairiness characteristics.
\end{abstract}

Keywords: Cotton knit fabric, mechanical singeing, chemical singeing, brightness, whiteness, yellowness, strength, CMC pass fail, surface hairiness.

\section{INTRODUCTION}

Woven or knit fabrics both contain hairy or protruding fibers. To remove hairy or protruding fiber generally mechanical singeing such as gas singeing is done in case of woven fabric and chemical singeing is done in case of knit fabric. But in present some industries are using mechanical singeing in case of knit fabric also. Obviously there might be some relevant causes to use mechanical singeing .The main object of our research was to find out the reasons of using mechanical singeing. Its merits or demerits were also investigated in details.

Generally for knit fabric chemical singeing (Enzyme treatment) is done but recently used mechanical singeing so told that it is new innovation process and principally find out what are the benefits and why it used industry. Hence it is a new innovation process in previous there is no work regarding this process and don't find any published or journal. It is the first job and try to find satisfied results.
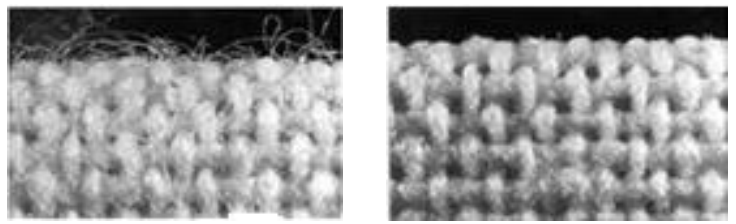

Fig1: Surface hairiness of unsigned and singed fabric

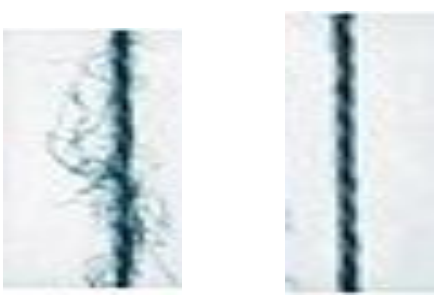

Fig: 2 Hairiness of unsinged and singed yarn

In this type of singeing machine, the fabric passes over a burning gas flame at such a speed that only the protruding fibres burn and the main body of the fabric is not damaged by the flame[9(c-j)]. This is the most common type of machine used for singeing fabrics as well yarns (Fig.).

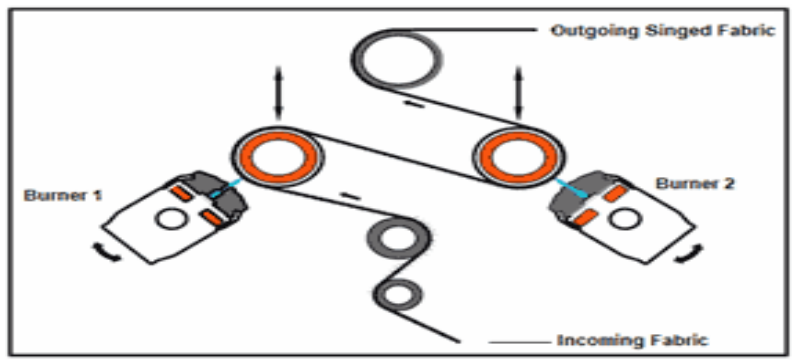

Fig: 3 Line Diagram of Gas Singeing Machine for Woven Fabrics 


\subsection{Fundamentals of Gas Singeing}

The main purpose of singeing is to burn the protruding fibres from the yarn and/or fabric surface. In order to burn the protruding fibres, energy must be supplied[9(c-j)]. The supplied energy must be just enough to burn only the protruding fibres, while keeping the firmly bound fibres in tact. This is achieved by allowing time of contact between the singeing flame and the fabric to practically a fraction of a second. As the temperature of the flame is too high (around $1300^{\circ} \mathrm{C}$ ), any regulation of this temperature is out of the question. However, metering and control of thermal energy of the flame is essential for the safe but effective burning off process.

\subsection{Fundamentals of Chemical Singeing}

Generally chemical singeing is done for knitted fabric. Basically Enzyme singeing called Chemical singeing [1-7]. Here we discussed about callulase which is used chemical singeing of knitted fabric. Cellulase refers to a class of enzymes produced chiefly by fungi, bacteria, and protozoans that catalyze cellulolysis (i.e. the hydrolysis of cellulose). However, there are also cellulases produced by a few other types of organisms, such as some termites and the microbial intestinal symbionts of other termites. Several different kinds of cellulases are known, which differ structurally and mechanistically.

Reaction: Hydrolysis of 1,4-beta-D-glycosidic linkages in cellulose, lichenin and cereal beta-D-glucans[1-7]. Other names for 'endoglucanases' are: endo-1,4-beta-glucanase, carboxymethyl cellulase (CMCase), endo-1,4-beta-Dglucanase, beta-1,4-glucanase, beta-1,4-endoglucan hydrolase, and celludextrinase. The other types of cellulases belong to exocellulases. Beta-glucosidases can also be considered as yet another group of cellulases. The expression 'avicelase' refers to the total cellulase activity of a given sample of the enzyme. The cellulase may be the result of the action of more than one type of enzymes.

In the most familiar case of cellulase activity, the enzyme complex breaks down cellulose to beta-glucose [1-7]. This type of cellulase is produced mainly by symbiotic bacteria in the ruminating chambers of herbivores. Aside from ruminants, most animals (including humans) do not produce cellulase in their bodies and can only partially break down cellulose through fermentation, limiting their ability to use energy in fibrous plant material. Enzymes that hydrolyze hemicellulose are usually referred to as hemicellulase and are usually classified under cellulase in general. Enzymes that cleave lignin are occasionally classified as cellulase, but this is usually considered erroneous.

\subsection{Mechanism of Cellulolysis}

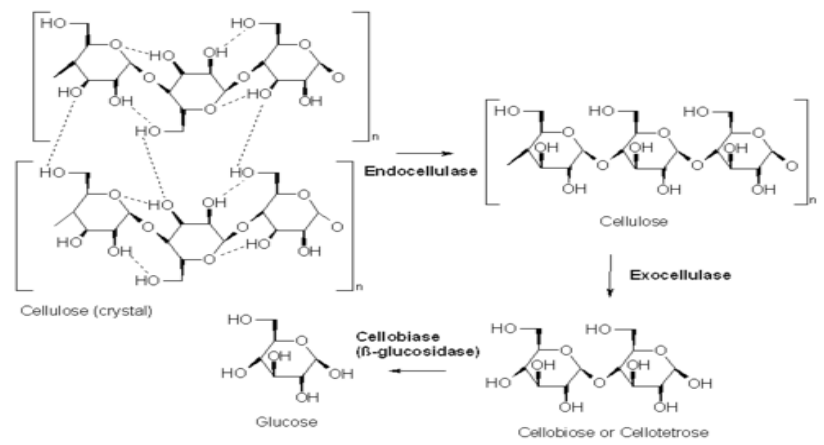

Fig: 4 Mechanism of cellulolysis

The three types of reaction catalyzed by cellulases[1-7]:1. Breakage of the noncovalent interactions present in the crystalline structure of cellulose (endocellulase) 2. Hydrolysis of the individual cellulose fibers to break it into smaller sugars (exocellulase) 3. Hydrolysis of disaccharides and tetrasaccharides into glucose (beta-glucosidase)

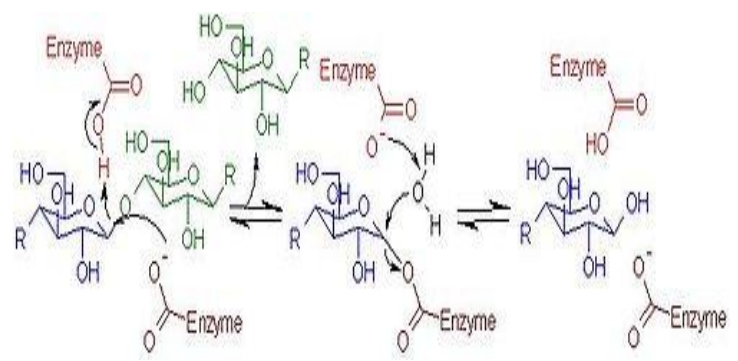

Fig: 5 Mechanistic details of beta-glucosidase activity of cellulose

\section{MATERIALS AND METHODS}

\subsection{Raw Materials}

The following raw materials were used

1. Fabric: Grey knitted fabric (Single Jersey).

Fabric Specification:

Fabric type : Single jersey

Count of yarn $\quad: 24 / \mathrm{s} \mathrm{comb}$

GSM $\quad: 180$

Stitch length $\quad: 2.75 \mathrm{~mm}$

Machine dia/gauge : :30x24"

Delivery dia : $62^{\prime \prime}$

Lot No. :525

Weight of fabric : $16 \mathrm{~kg}$ (8kg mechanical singeing $+8 \mathrm{~kg}$ chemical singeing) 


\subsection{Operational sequence for fabric processing}

\begin{tabular}{|l|l|}
\hline $\begin{array}{l}\text { For Mechanical } \\
\text { singeing }\end{array}$ & For Chemical singeing \\
\hline $\begin{array}{l}\text { Mechanical } \\
\text { singeing }\end{array}$ & Scouring \\
Scouring & Bleaching \\
Bleaching & Enzyme treatment (chemical \\
Dyeing & singeing) \\
\hline
\end{tabular}

\subsection{Mechanical Singeing}

Machine Specification:

Name of Machine

: Mechanical Singeing Machine

Brand name

: Osthoff-senge

Company name

:TEXTILE MASCHINEN(VDMA)

Origin

: Germany

Model

: WW2006

Machine rpm

specification)

Flame length specification)

Gas pressure

: $65 \mathrm{~m} / \mathrm{min}$ (depend on fabric

: $13 \mathrm{~mm}$ (Depend of fabric

: $1.4 \mathrm{mbar}$

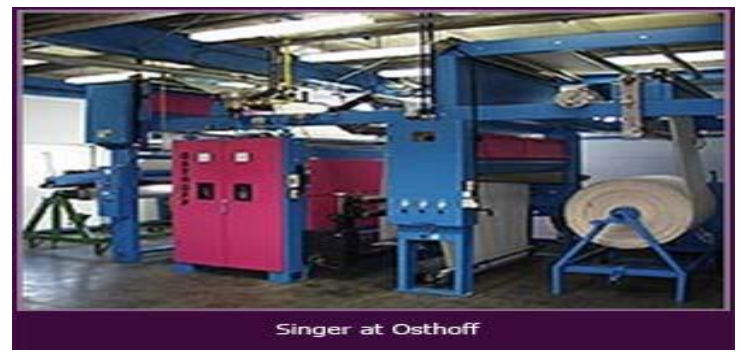

Fig: 6 Mechanical singeing Machine

\subsection{Hydraulic Bursting Strength Test}

\section{Sample Preparation:}

The specimen for this test should be cut so that the sample is $1 / 2$ inch greater in diameter than the outside diameter of the clamp ring. Ten specimens are chosen avoiding inclusion of the same ends in the different specimens. The clamp ring should have an internal diameter of 1.20 inches

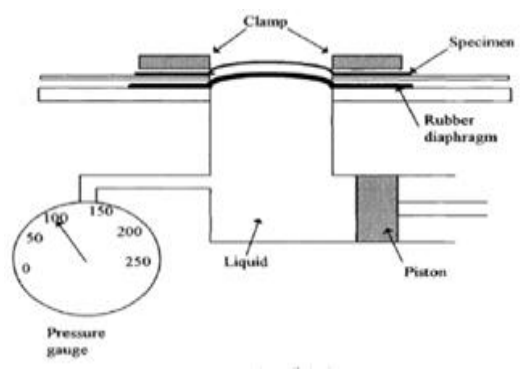

Fig 7: Hydraulic Bursting tester

\section{RESULTS AND DISCUSSIONS}

\subsection{Whiteness for Chemically and Mechanically Singed Fabric}

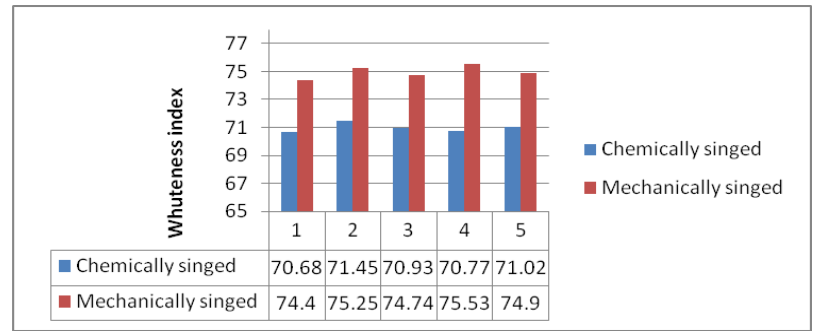

Fig: 8 Graphical presentation of Whiteness of enzyme treated (chemically singed) and mechanically singed fabric

\subsection{Brightness for Chemically and Mechanically} Singed Fabric

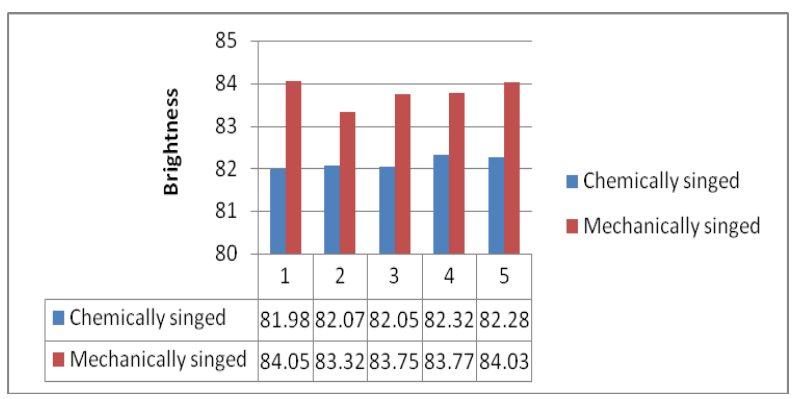

Fig: 9 Graphical presentation of Brightness of enzyme treated (chemically singed) and mechanically singed fabric

\subsection{Yellowness of Chemically and Mechanically}

\section{Singed Fabric}

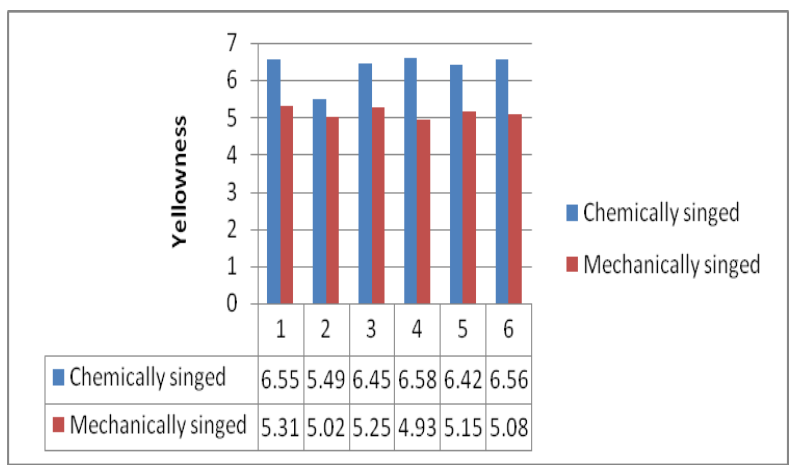

Fig: 10 Graphical presentations to Yellowness of chemically and mechanically singed fabric

Considering experimental results in table 3.1 shows that average whiteness variation between enzyme and mechanically singed fabric sample is 4.17. Individual 
mechanically singed sample shows more whiteness than enzyme treated ones. Results concerning table 3.2 also show more brightness for mechanically singed samples. Table 3.3 shows less yellowness for mechanically singed samples. From above two tables (table 3.1 and 3.2) whiteness and brightness results are better of mechanically singed samples than enzyme or chemically singed samples it might be the cause when mechanical singeing is perform it abraded the fabric surface by beating roller, brushing or flex roller with flame resulting elimination of hairy or protruding fibers and fabric surface smoothing. In addition table 3.3 shows more yellowness shows for enzyme treated or chemically singed fabric than mechanically singed fabric.

\subsection{Color Fastness to Wash}

In this experiment color fastness assessments are used for dyed fabric and after finishing of fabric (chemically and mechanically singed) .For color fastness tests are used for perspiration, washing and rubbing test because they lead more for color fading of fabric and staining of other fabrics. Following table shows the test results.

Table: 1 Color fastness to Wash after dyeing enzyme treated and mechanically singed fabric

\begin{tabular}{|c|c|c|c|}
\hline Sl. & Description of Test & \multicolumn{2}{|c|}{ Test Result(Grade) } \\
\hline \multirow[t]{2}{*}{01} & $\begin{array}{l}\text { Colorfastness to } \\
\text { Wash } \\
\text { Method Followed: } \\
\text { ISO105 C03 }\end{array}$ & $\begin{array}{l}\text { Enzyme } \\
\text { treated }\end{array}$ & $\begin{array}{l}\text { Mechanically } \\
\text { Singed }\end{array}$ \\
\hline & $\begin{array}{l}\text { Color change in } \\
\text { shade }\end{array}$ & $4 / 5$ & $4 / 5$ \\
\hline & \multicolumn{3}{|c|}{ Degree of Staining grey scale } \\
\hline & Acetate & $4 / 5$ & $4 / 5$ \\
\hline & Cotton & 4 & 4 \\
\hline & Polyamide & $4 / 5$ & $4 / 5$ \\
\hline & Polyester & $4 / 5$ & $4 / 5$ \\
\hline & Acrylic & 4 & 4 \\
\hline & Wool & 4 & $3 / 5$ \\
\hline \multicolumn{4}{|c|}{$\begin{array}{l}\text { Interpretation of grade: (5) Excellent (4) Good (3) Fair (2) } \\
\text { Poor (1) Very Poor } \\
\text { Range of Testing/Limit of Detection: } 1 \text { to } 5 \text { grade } \\
\text { Accuracy }( \pm): 0.5 \text { Grade }\end{array}$} \\
\hline
\end{tabular}

\subsection{Bursting Strength}

Table: 2 Bursting strength after finishing enzyme treated and mechanically singed fabric

\begin{tabular}{|l|l|l|l|l|}
\hline $\begin{array}{l}\text { Sl. } \\
\text { No. }\end{array}$ & \multicolumn{2}{|l|}{$\begin{array}{l}\text { After finishing } \\
\text { (Enzyme treated) }\end{array}$} & \multicolumn{2}{|l|}{$\begin{array}{l}\text { After finishing } \\
\text { (Mechanically singed) }\end{array}$} \\
\hline & $\begin{array}{l}\text { Strength } \\
\text { results } \\
\text { (psi) }\end{array}$ & $\begin{array}{l}\text { Average } \\
\text { strength }\end{array}$ & $\begin{array}{l}\text { Strength } \\
\text { results } \\
\text { (psi) }\end{array}$ & $\begin{array}{l}\text { Average } \\
\text { strength }\end{array}$ \\
\hline
\end{tabular}

\begin{tabular}{|l|l|l|l|l|}
\hline 01 & 84 & \multirow{3}{*}{$84 \mathrm{psi}$} & 78 & \multirow{3}{*}{$80 \mathrm{psi}$} \\
\cline { 1 - 1 } 02 & 80 & & 82 & \\
03 & 86 & & 81 & \\
\cline { 1 - 1 } 04 & 86 & & 79 & \\
& & & \\
\end{tabular}

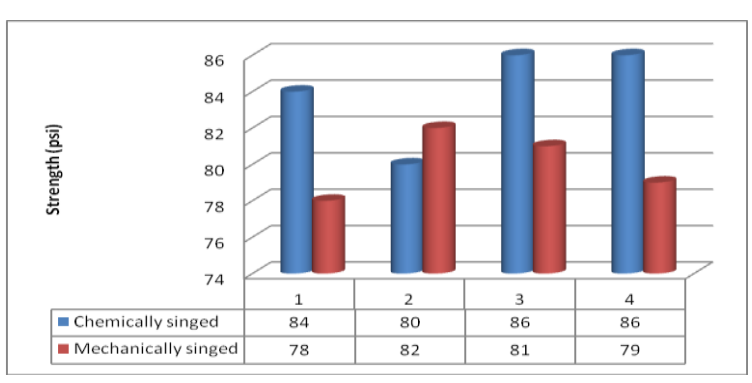

Fig: 11 Graphical presentation of strength of enzyme treated and mechanically singed fabric.

Enzyme treated fabric shows better bursting strength result than mechanically singed fabric. it might be caused mechanically singed fabric faced more tensile stress, and easy removed of the protruding fiber.

\subsection{Microscopic View}
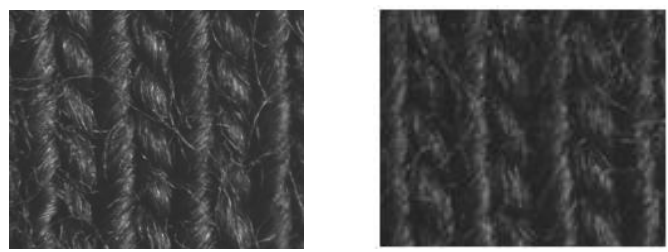

Fig: 12 Microscopic view of mechanically and chemically singed fabric

In above figures shows microscopic view of fabric surface and discussed that chemically singed is better performed to remove hairy fiber from the fabric surface than mechanical singeing

\subsection{Shade Matching (CMC) pass fail}

Table: 3 Shade matching of Enzyme treated and mechanically singed fabric

\begin{tabular}{|l|l|l|l|l|l|}
\hline $\begin{array}{l}\text { S1. } \\
\text { No. }\end{array}$ & Process & $\begin{array}{l}\text { CMC } \\
\text { DE }\end{array}$ & $\begin{array}{l}\text { DE* } \\
\text { (D65 } \\
10 d e g \\
)\end{array}$ & Remarks \\
\hline 01 & $\begin{array}{l}\text { Enzyme } \\
\text { treated after } \\
\text { dyeing vs } \\
\text { Mechanically } \\
\text { singed after } \\
\text { dyeing }\end{array}$ & $\begin{array}{l}0.30 \\
\text { (pass) }\end{array}$ & 0.37 & Darker & $\begin{array}{l}\text { Mor } \\
\text { e red }\end{array}$ \\
\hline
\end{tabular}




\begin{tabular}{|l|l|l|l|l|l|}
\hline 02 & $\begin{array}{l}\text { Enzyme } \\
\text { treated after } \\
\text { finishing vs } \\
\text { Mechanically } \\
\text { singed after } \\
\text { finishing }\end{array}$ & $\begin{array}{l}0.61 \\
\text { (pass) }\end{array}$ & 0.92 & Darker & $\begin{array}{l}\text { Mor } \\
\text { e red }\end{array}$ \\
\hline
\end{tabular}

Considering the table 3.4, mechanically singed fabric got better color saturation capability than chemically singed fabric.

\section{CONCLUSIONS}

Although chemical singeing is being used for knit fabric singeing but now-a-days mechanical singeing is also being used for the same. Keeping relation to this concept single jersey cotton knit fabric of 162 gsm were singed both chemically and mechanically in this research work. The result shows better whiteness and brightness of mechanically singed fabric than chemically singed because of mechanical singeing abraded the fabric surface and surface become smoother. Chemically singed fabric also shows greater yellowness than mechanical ones. Mechanically singed fabric got better color saturation capability than chemically singed fabric. Different color fastness value (Washing, Rubbing and Perspiration) were same for both types of samples. The results revealed that there was no significant difference on color fastness properties between chemically singed or enzyme treated and mechanically singed dyed fabrics. Chemically singed fabric shows better bursting strength than mechanically singed fabric. Considering the cost, chemical singeing were more cost effective ( 7 taka per $\mathrm{kg}$ fabric) than mechanical singeing (13 taka per $\mathrm{kg}$ fabric). In case of blend fabric mechanical singeing was significant because Enzyme (chemically singed), which contain cellulase, attacks only single cellulose fiber and removing protruding fibers from the fabric surface. However, blended fiber which restrain cellulose and other fibers or fully contain supplementary fibers. If used enzyme in blended fabric it attack only cellulose not others fibers resulting protruding fibers remove not noticeably from the fabric flat surface. In case of high quality cotton mature fiber Cellulase Enzyme not working properly this type of fiber surface (Such as American PIMA, Sudan, Upland cotton). Hence, in this situation mechanical singeing was better instead of chemical singeing. Moreover, Cellulase Enzyme efficiently working particular fiber but pill of fabric which have high congregate fiber. So chemical singeing for pill fabric seems to be less susceptive, even it is time consuming and acid not working properly. For check and stripe fabric, mechanical singeing is better than chemical singeing because chemical singeing might affect on check and stripe pattern for lack in sharp outlining. Lastly, it can be conclude that chemical and mechanical singeing both are important for removing hairy or protruding fiber from knit fabric surface. In modern industry, scopes for both process should be available for entirely fulfillment buyer or customers requirement.

\section{REFERENCES}

[1]. Chapin III, F.S., P.A. Matson, H.A. Mooney. Principles of Terrestrial Ecosystem Ecology. Springer-Verlag New York, NY. 2002.

[2]. PDB 1NLR; Sulzenbacher G, Shareck F, Morosoli R, Dupont C, and Davies GJ (1997). "The Streptomyces lividans family 12 endoglucanase: construction of the catalytic cre, expression, and X-ray structure at $1.75 \AA$ resolution".

[3]. Biochemistry 36:1603216039. doi:10.1021/bi972407v.

PMID 9440876.; rendered with PyMOL The Merck Manual of Diagnosis and Therapy, Chapter 24, A cellulase gene of termite origin.

[4]. Watanabe H., Hiroaki Noda, Tokuda G., Lo N. 1998 Nature 394, 330-331;

[5]. Andreas Brune and Moriya Ohkuma, "Role of the termite gut macrobiota in symbiotic digestion", in David Edward Bignell, ed., Biology of Termites: A Modern Synthesis 2010: ch. 16.

[6]. Enhancement of Cellulase Activity from a New Strain of Bacillus subtilis by Medium Optimization and Analysis with Various Cellulosic Substrates, Deepmoni Deka, P. Bhargavi, Ashish Sharma, Dinesh Goyal, M. Jawed, and Arun Goyal. Volume 2011 (2011),

[7]. Article ID 151656, 8 pages,Bayer E.A, Chanzy H., Lamed R., Shoham Y. (1998): Cellulose, Cellulases and Cellulosomes, Curr Opin Struc Biol 8: 548-557

[8]. Muhammad Iftikhar, Nisar Ahmad Jamil and Babar Shahbaz. Rubbing, Ironing and Dry Cleaning Fastness of Reactive Dyed Cotton Knitted Fabric as Influenced by Salt, Alkali and Dye., International Journal of Agriculture and Biology, Vol. 3,Issue 1, pp. 109-112,2001.

[9]. Website References

a. http://www.osthoff-senge.com/

b. http://www.swastiktextile.com/

c. http://www.lindauer-dornier.com/english/index.htm

d. http://www.menzelus.com

e. http://www.menzel.net

f. http://susiram.in

g. http://www.gayatri-engg.com

h. http://www.jfletcher.co.uk

i. http://www.ssm.ch

j. http://www.ritespa.it

k. http://textilelearner.blogspot.com/2011/08/color-fastness-torubbing-rubbing_1201.html

1. http://articles.textileclass.com/color-fastness-to-wash-oftextile-materials-fastness- measurement/ 